\title{
PENENTUAN FAKTOR SELEKTIFITAS PENISILIN G TERHADAP FENILASETAT SECARA EKSTRAKSI MEMBRAN CAIR EMULSI DENGAN MENGGUNAKAN CARRIER DIOKTILAMIN
}

Imam Santoso, Tritiyatma Hadinugraha Ningsih

Jurusan Kimia, Fakultas Matematika dan Ilmu Pengetahuan Alam, Universitas Negeri Jakarta, Rawamangun 13220, Jakarta

*Corresponding author: mutinurjayadi@yahoo.com

\begin{abstract}
Abstrak
Tujuan dpenelitian ini adalah untuk menentukan faktor selektifitas pemisahan penisilin $G$ dari fenilasetat. Cara penenlitian: ke dalam wadah yaitu reaktor (wadah tempat kontak antara fasa emulsi dengan fasa eksternal) dimasukkan $20 \mathrm{~mL}$ fasa eksternal buffer sitrat $\mathrm{pH}=5$ yang mengandung 372,5 ppm penisilin $\mathrm{G}$ dan 136,5 ppm fenilasetat. Emulsi yang stabil dicampurkan ke dalam reaktor tersebut diaduk dengan kecepatan $300 \mathrm{rpm}$ dan waktu kontak 5 menit. Setelah terjadi kontak antara fasa emulsi dengan fasa eksternal campuran didiamkan kemudian dipisahkan lalu diambil fasa emulsinya. Emulsi dipecahkan fasa internal yang mengandung penisilin $G$ ditentukan kuantitasnya dengan HPLC, Hasil penelitian memberikan data sebagai berikut : persen ekstraksi penislin G pada lama ekstraksi : 5 menit, 10 menit, 15 menit, 20 menit adalah : 35,74\%; \% ; 10,54\%; 10,05\%; 9,66\% lebih tinggi dibanding persen ekstraksi fenil asetat $15,13 \% ; 0,76 \% ; 0,57 \% ; 0,55 \%$. Akibatnya faktor selektifitas penisilin Gfenilasetat naik dari 2,1 sampai 21. Keadaan ini memberikan arti bahwa pada fasa internal kandungan penisilin $\mathrm{G}$ lebih banyak dibanding fenilasetat. Dengan demikian kesimpulan penelitian adalah cara ekstraksi membran cair emulsi dengan dioktilamin sebagai carrier merupakan cara yang efektif untuk memisahkan campuran penisilin $\mathrm{G}$ dari fenilasetat
\end{abstract}

Kata kunci : Membran cair emulsi, faktor daya pisah

\section{Pendahuluan}

Beberapa metode ekstraksi penisilin G yang telah dikembangkan oleh peneliti terdahulu antara lain : Reschke dan Schugerl mengembangkan teknik ekstraksi dua tahap yaitu fasa air pertama (larutan buffer sitrat) yang negnadung penisilin $g$ diekstraksi dengan pelarut organik $n$-butilasetat yang ditambahkan salah satu ke dalamnya senyawa reaktif seperti Amberlite LA-2, di- $n$-oktilamin dan tri- $n$-oktilamin sebagai ekstraktan. Penisilin G yang terekstraksi di fasa organik, fasa organiknya dipisahkan kemudian diekstraksi kembali dengan fasa air kedua (larutan buffer fospat). Esktraksi dilakukan dengan kondisi $\mathrm{pH}$ tengah di mana penisilin $G$ relatif stabil. Pada kondisi ini penisilin $G$ yang didapat mencapai $\geq 98 \%$. (Reschke,1984).

Proses pemisahan penisilin ini akhirnya dikembangkan menjadi satu tahap ekstraksi di mana ekstraksi dan reekstraksi terdapat di dalamnya. Seperti yang telah dilakukan oleh N.Li pada proses pemisahan fenol dan senyawa-senyawa yang bersifat asam lemah atau basa lemah pada tahun 1968. Tadhasi Hano menggunakan teknik membran cair untuk pemisahan penisilin G. Di-n-oktilamin (DOA) sebagai carrier, ECA 4360J sebagai surfaktan dan $n$-butilasetat, kerosin atau campuran keduanya sebagai pelarut organik. Larutan $\mathrm{Na}_{2} \mathrm{CO}_{3}$ sebagai fasa internal sedangkan untuk menjaga $\mathrm{pH}$ larutan penisilin $\mathrm{G}$ digunakan buffer sitrat. Dalam waktu beberapa menit penisilin $G$ yang terekstraksi mencapai $\geq 99 \%$. (Hano,1990 dan 1994).

Melihat bahwa kedua cara ekstraksi membran cair emulsi memberikan persen ekstraksi yang tinggi, maka pada penelitian ini akan dicoba menentukan faktor selektifitas penisilin G-fenil asetat dengan teknik tersebut.

Kemampuan suatu komponen dapat tertransport ke dalam fasa internal melalui membran cair emulsi salah satunya dipengaruhi oleh luas butiran emulsi. Oleh karena itu faktor selektifitas pada ekstraksi secara membran cair emulsi dapat ditentukan melalui perbandingan permeabilitas masing- 
masing komponennya. Permeabilitas adalah kemampuan suatu komponen untuk menembus fasa butiran emulsi pada luas tertentu persatuan waktu. Konsentrasi penisilin yang melewati lapisan perbatasan membran ditulis sebagai persamaan fluks pada lapis batas, $\mathrm{J}_{\mathrm{bl}}$ berikut ini :

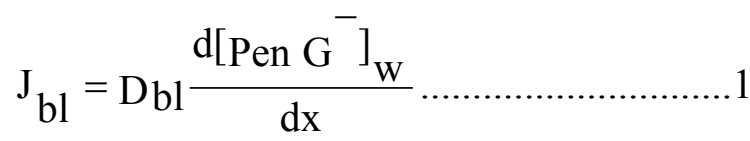

sementara penisilin yang berbentuk senyawa kompleks yang melewati permukaan diungkapkan menurut persamaan fluks pada permukaan $\mathrm{J}_{\mathrm{i}}$, berikut ini :

$$
\mathrm{J}_{\mathrm{i}}=\mathrm{k}_{1}\left[\text { Pen } \mathrm{G}^{-}\right]_{\mathrm{W}}-\mathrm{k}-1\left[\text { Pen } \mathrm{G}^{-}\right]_{\mathrm{m}} \ldots \ldots . .2
$$

dalam hal ini $\mathrm{k}_{1}$ dan $\mathrm{k}_{-1}$ masing-masing adalah konstanta kecepatan transport dari fasa air ke fasa membran dan sebaliknya, [Pen $\left.\mathrm{G}^{-}\right]_{\mathrm{w}}$ dan $\left[\text { Pen } \mathrm{G}^{-}\right]_{\mathrm{m}}$ masing-masing adalah konsentrasi ion penisilin dalam fasa air dan fasa membran yang berada di permukaan antara fasa air dan fasa membran $(\mathrm{m})$.

Penisilin yang melewati fasa membran diungkapkan menurut persamaan fluks pada membran $\mathrm{J}_{\mathrm{m}}$ :

$$
\mathrm{J}_{\mathrm{m}}=-\mathrm{D}_{\mathrm{Dm}} \frac{\mathrm{d}\left[\text { Pen } \mathrm{G}^{-}\right]_{\mathrm{W}}}{\mathrm{dx}} \ldots \ldots \ldots \ldots \ldots . . .3
$$

Dalam keadaan steady-state semua fluks adalah sebanding $\mathrm{J}_{\mathrm{bl}}=\mathrm{J}_{\mathrm{i}}=\mathrm{J}_{\mathrm{m}}$. Kombinasi persamaan ketiganya memberikan :

$$
\begin{aligned}
& \mathrm{J}=\frac{\left.\mathrm{k}_{1} \text { [Pen } \mathrm{G}^{-}\right]_{\mathrm{W}}}{\mathrm{k}_{1} \frac{\delta}{\mathrm{D}_{\mathrm{bl}}}+\mathrm{k}_{-1} \frac{1}{\mathrm{D}_{\mathrm{m}}}+1} \ldots \ldots \ldots \ldots \ldots . . . . . .4
\end{aligned}
$$

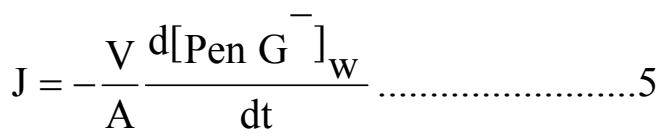

di mana $\mathrm{V}$ adalah volume total fasa umpan dan A luas membran. Diasumsikan kecepatan pembentukan kompleks sangat cepat, maka :

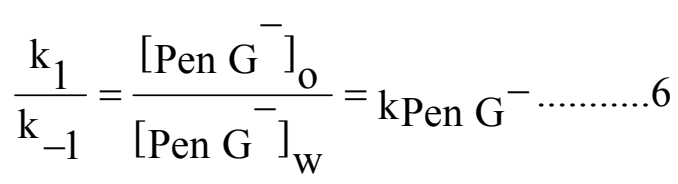

dengan membagi $\mathrm{k}_{-1}$ pada Persamaan 4 dan mengabaikan angka 1, maka persamaan menjadi :

$$
\frac{\mathrm{J}}{\left[\mathrm{Pen}^{-}\right]_{\mathrm{W}}}=\frac{\mathrm{kPen} \mathrm{G}^{-}}{\mathrm{k}_{3}-\frac{\delta}{\mathrm{D}_{\mathrm{bl}}}+\frac{1}{\mathrm{D}_{\mathrm{m}}}} \ldots \ldots \ldots \ldots . . .7
$$

Jika permeasi hanya ditentukan oleh proses difusi yang melalui membran, sedang yang melalui lapisan perbatasan (boundary layer) diabaikan, maka koefisien permeabilitas $(\mathrm{P})$ dituliskan $\mathrm{P}=\mathrm{K}_{\mathrm{Pen}} \mathrm{G}^{-} \cdot \mathrm{D}_{\mathrm{m}} / 1$. Kombinasi Persamaan 5 dan 7 , dan integrasi dengan batas : $\mathrm{C}=\mathrm{C}_{0}$ dan $\mathrm{t}=0$ hingga $\mathrm{C}=\mathrm{C}$ dan $\mathrm{t}=\mathrm{t}$

maka persamaan akhirnya adalah :

$$
\ln \left(\frac{\mathrm{C}}{\mathrm{c} 0}\right)=-\frac{\mathrm{A}}{\mathrm{V}} \mathrm{P} . \mathrm{t}
$$

$\mathrm{C}=$ Konsentrasi setelah ekstraksi

$\mathrm{C}_{0}=$ Konsentrasi mula-mula

$\mathrm{A}=$ Luas butiran emulsi

$\mathrm{V}=$ Volume fasa umpan

$\mathrm{P}=$ Permeabilitas

\section{Metodologi Penelitian}

\subsection{Alat dan Bahan}

Penisilin G dan fenilasetat hasil ekstraksi ditentukan kuantitasnya dengan HPLC merk Waters 247, dengan detektor UV. Pengukuran $\mathrm{pH}$ ditentukan dengan $\mathrm{pH}$ meter merek HANNA. Untuk pemecah emulsi digunakan alat electric deemulsifier dengan frekuensi $250 \mathrm{KHZ}$ dan voltase 76 volt AC. Stirer reaktor memiliki kecepatan $100 \mathrm{~s} / \mathrm{d} 600 \mathrm{rpm}$, sedangkan stirer pembuat emulsi memiliki kecepatan $1000 \mathrm{~s} / \mathrm{d} 10.000 \mathrm{rpm}$.

Alat gelas yang digunakan adalah alat gelas yang lazim digunakan dilaboratorium kimia.. Reaktor untuk tempat kontak antara fasa emulsi dengan fasa umpan berkapasitas $250 \mathrm{~mL}$ dilengkapi aliran air sebagai pengatur suhu. Wadah pemisah emulsi berkapasitas $20 \mathrm{~mL}$.

\subsection{Bahan}

Kristal Asam sitrat $\left.\left(\mathrm{C}_{6} \mathrm{H}_{8}\right)_{7} \cdot \mathrm{H}_{2} \mathrm{O}\right)$ SIGMA, kristal garam sitrat $\left(\mathrm{C}_{6} \mathrm{H}_{5} \mathrm{O}_{7} \mathrm{Na}_{3} .2 \mathrm{H}_{2} \mathrm{O}\right)$ SIGMA.Kristal garam posfat 
$\left(\mathrm{Na}_{2} \mathrm{HPO}_{4} .2 \mathrm{H}^{2} \mathrm{O}\right)$ SIGMA, kristal garam posfat $\left(\mathrm{NaH}_{2} \mathrm{PO}_{4} \cdot \mathrm{H}_{2} \mathrm{O}\right)$ SIGMA, pelarut $n$ butyl asetat, kerosen (SIGMA), dioktilamin (aldrich) merupakan bahan kimia yang digunakan pada penelitian ini dan memiliki kualitas proanalysis(pa).

\subsection{Cara Kerja}

Penentuan Daya Pisah Penisilin G-Fenilasetat secara Ekstraksi Membran Cair Emulsi.

a. Waktu Kontak 5 menit

\section{Membuat Fasa Emulsi}

$10 \mathrm{~mL}$ fasa membran mengandung $5 \%$ span 80, 0,002 M dioktilamin dengan perbandingan kerosen : $n$-butilasetat adalah 1 : 1. Fasa membran tersebut dimasukkan ke dalam gelas kimia $100 \mathrm{~mL}$ kemudian ke dalam gelas kimia ditambahkan $10 \mathrm{~mL}$ fasa internal yaitu buffer posfat $\mathrm{pH}=8$, diaduk dengan stirer dengan kecepatan 2000 rpm selama 1 menit. Emulsi yang terbentuk dibiarkan selama 13 menit.

Proses kontak dengan fasa eksternal

Ke dalam wadah yang lain yaitu reaktor (wadah tempat kontak antara fasa emulsi dengan fasa eksternal) dimasukkan $20 \mathrm{~mL}$ fasa eksternal buffer sitrat $\mathrm{pH}=5$ yang mengandung 372,5 ppm penisilin $\mathrm{G}$ dan 136,5 ppm fenilasetat. Emulsi yang telah didiamkan selama 13 menit, bagian emulsi yang stabil dicampurkan ke dalam reaktor tersebut diaduk dengan kecepatan 300 rpm dan waktu kontak 5 menit. Setelah terjadi kontak antara fasa emulsi dengan fasa eksternal campuran didiamkan.
Proses Deemulsifikasi

Setelah terjadi pemisahan, fasa emulsi diambil dan dimasukkan ke dalam wadah yang telah dihubungkan dengan alat pemecah emulsi. Emulsi yang pecah akan menghasilkan 2 (dua) lapisan yaitu lapisan air yang mengandung penisilin $\mathrm{G}$ dan fenil asetat dan lapisan fasa organik.

\section{Proses Pengukuran}

Analisis kandungan penisilin $G$ dan fenilasetat pada lapisan air ditentukan melalui HPLC dengan kondisi sebagai berikut : eluen 0,01M NH $\mathrm{NH}_{2} \mathrm{PO}_{4}$ : Metanol = $7:$ 3; flow rate1 $\mathrm{mL} / \mathrm{menit}$; Kolom C8. Panjang Gelombang $225 \mathrm{~nm}$.

b. Waktu Kontak 10 menit

Sama seperti langkah a hanya waktu kontak antara fasa emulsi dengan fasa umpan $10,15,20$ menit

\section{Hasil dan Pembahasan}

Penentuan Faktor Selektifitas Penisilin GFenilasetat secara Membran Cair Emulsi

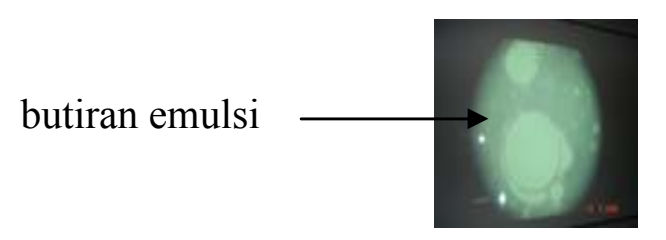

Gambar 1 : Penentuan diameter butiran emulsi

Kemampuan suatu komponen dapat tertranspor ke dalam fasa internal melalui membran cair emulsi salah satunya dipengaruhi oleh luas butiran emulsi. Penentuan luas butiran emulsi dilakukan melalui pengukuran diameter butiran emulsi dengan luve yang diperbesar 100 kali.

Table 1. Perhitungan Faktor Daya Pisah Penisilin G-Fenilasetat dengan Cara Perbandingan Permeabilitas pada Ekstraksi Membran Cair Emulsi

\begin{tabular}{|c|l|l|l|l|l|l|l|l|c|}
\hline \multirow{2}{*}{$\begin{array}{c}\text { Waktu } \\
\text { Kontak } \\
\text { (menit) }\end{array}$} & \multicolumn{5}{|c|}{ Penisilin G } & \multicolumn{5}{c|}{ Fenil asetat } & \multirow{2}{*}{ Selektifitas } \\
\cline { 2 - 11 } & $\mathrm{T}_{\mathrm{R}}$ & Luas Kurva & $\mathrm{C}(\mathrm{ppm})$ & $\mathrm{P}_{\text {pen G }}$ & $\mathrm{T}_{\mathrm{R}}$ & Luas Kurva & $\mathrm{C}$ & $\mathrm{P}_{\text {Fenas }}$ & \\
\hline 5 & 8.290 & 186926 & 133,13 & 3,6 & 4.34 & 487311 & $20,60 \mathrm{ppm}$ & 1,33 & 2,7 \\
\hline 10 & 7.633 & 55149 & 39,30 & 0,45 & 4.543 & 24791 & $1,05 \mathrm{ppm}$ & 0,032 & 14,06 \\
\hline 15 & 7.007 & 52612 & 37,47 & 0,31 & 4.303 & 18389 & $0,78 \mathrm{ppm}$ & 0,016 & 19,38 \\
\hline 20 & 6.577 & 50541 & 35,99 & 0,21 & 4.310 & 17967 & $0,76 \mathrm{ppm}$ & 0,01 & 21 \\
\hline
\end{tabular}


Dari hasil pengamatan pada gambar 1. di dapat diameter butiran emulsi $\pm 0,1 \mathrm{~mm}$, maka $r=0,05 \mathrm{~mm}$, dengan demikian butiran emulsi memiliki luas $7,85 \times 10^{-3} \mathrm{~mm}^{2}$. Faktor daya pisah pada ekstraksi secara membran cair emulsi ditentukan melalui perbandingan permeabilitas komponennya masing-masing. Ungkapan permeabilitas yang digunakan adalah (Mulder,1996) :

$\operatorname{Ln}\left(\mathrm{C} / \mathrm{C}_{0}\right)=-\mathrm{A} / \mathrm{V}$. P.t

di mana :

$\mathrm{C}=$ Konsentrasi setelah ekstraksi

$\mathrm{C}_{0}=$ Konsentrasi mula-mula

$\mathrm{A}=$ Luas butiran emulsi

$\mathrm{V}=$ Volume fasa umpan

Perhitungan permeabilitas untuk penisilin $G$ dan fenilasetat adalah seperti pada tabel 1 . Tabel dan alur antara waktu kontak terhadap persen ekstraksi dapat dilihat pada tabel 2 dan gambar 2.

Tabel 2. Waktu Kontak terhadap Persen Ekstraksi Penisili G dan Fenilasetat

\begin{tabular}{|c|c|c|}
\hline $\begin{array}{l}\text { Waktu } \\
\text { Kontak } \\
\text { (menit) }\end{array}$ & $\begin{array}{l}\text { Persen } \\
\text { Esktraksi } \\
\text { Fenil } \\
\text { Asetat }\end{array}$ & $\begin{array}{l}\text { Persen } \\
\text { Ekstraksi } \\
\text { Penisilin G }\end{array}$ \\
\hline 5 & 15,13 & 35,74 \\
\hline 10 & 0,76 & 10,54 \\
\hline 15 & 0,57 & 10,05 \\
\hline 20 & 0,55 & 9,66 \\
\hline
\end{tabular}

Dari gambar 2 terlihat bahwa persen ekstraksi baik penisilin $\mathrm{G}$ maupun fenilasetat sama-sama menurun dan penurunan terhenti pada waktu kontak 10 menit. Salah satu penyebab turunnya persen ekstraksi kedua komponen tersebut adalah karena ada emulsi yang tidak stabil.

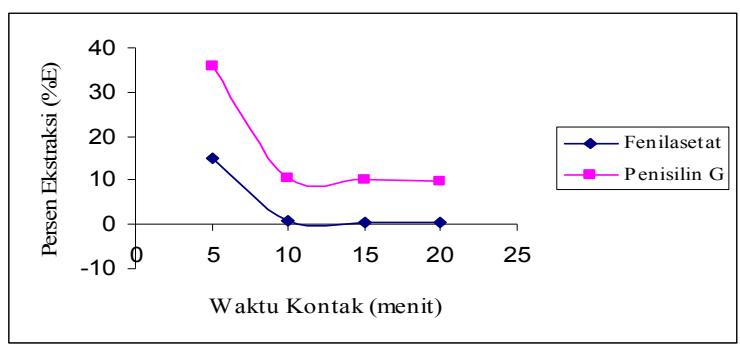

Gambar 2. Kuva waktu kontak terhadap persen ekstraksi penisilin $\mathrm{G}$ dan fenilasetat
Terdapat emulsi yang pecah ketika diaduk dengan kecepatan dan lamanya waktu pada saat kontak dengan fasa eksternal. Sehingga penisilin $G$ dan fenilasetat yang telah tertranspor di fasa internal kembali keluar ke fasa eksternal. Persen ekstraksi yang terukur pada gambar 2 adalah persen ekstraksi hasil pengukuran penisilin $\mathrm{G}$ dan fenilasetat dari emulsiyang stabil.

Walaupun persen ekstraksi penisilin $\mathrm{g}$ dan fenilasetat sama-sama menurun, tetapi penisilin $G$ memberikan kandungan yang lebih tinggi dibanding fenilasetat. Hal yang sama terjadi pada permeabilitas penisilin G dan fenilasetat. Pada gambar 3 terlihat bahwa permeabilitas penislin $G$ dan fenilsetat juga menurun tetapi stabil pada waktu kontak 10 menit. Namun demikian permeabilitas penisilin $G$ lebih tinggi dibanding permeabilitas fenilasetat

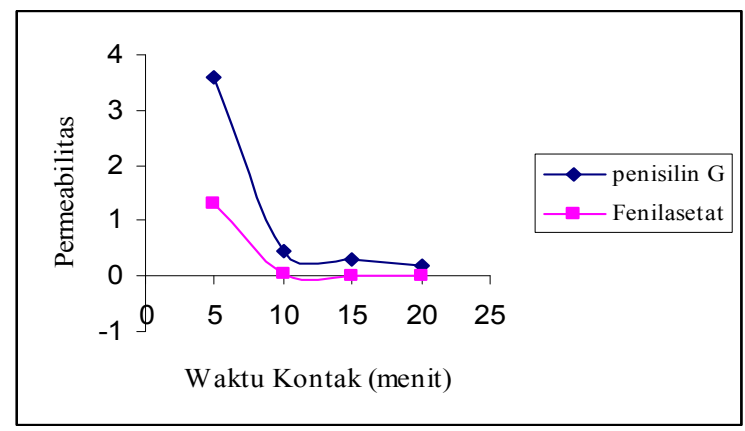

Gambar 3. Kuva waktu kontak terhadap permeabilitas penisilin $\mathrm{G}$ dan fenilasetat

Hal ini berarti kemampuan penembusan penisilin $G$ terhadap butiran emulsi lebih tinggi dibanding fenilasetat. Jika permeabilitas penisilin $\mathrm{G}$ dibandingkan dengan permeabilitas fenilasetat, maka akan didapat faktor selektifitas seperti pada gambar 4.

Faktor selektifitas penisilin G-fenilasetat cenderung meningkat dan mendatar pada waktu kontak 15 menit. Pada kondisi ini fasa penerima (internal) lebih banyak mengandung penisilin $G$ dibanding fenilasetat. Data ini sesuai dengan tujuan penelitian yaitu penisilin $G$ dapat dipisahkan dengan fenilasetat dengan faktor selektifitas yang tinggi yaitu 21 . Dengan demikian cara ekstraksi membran cair emulsi dengan dioktilaminsebagai cariier 
dapat digunakan untuk memisahkan penisilin $\mathrm{G}$ dari fenilasetat walaupun perolehan persen ekstraksi penisilin $\mathrm{G}$ yang masih relatif kecil.

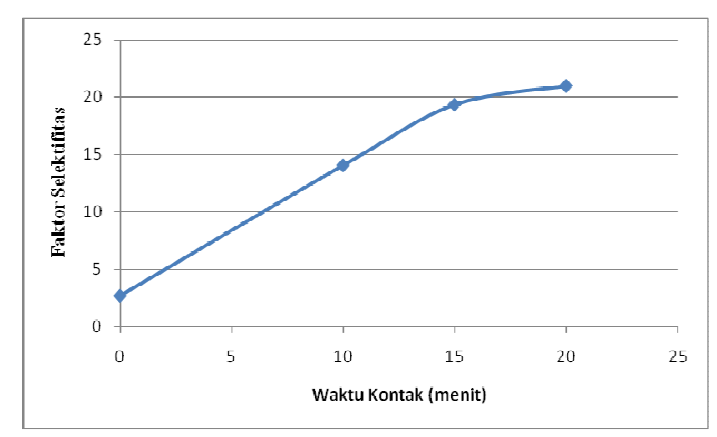

Gambar 4. Kuva waktu kontak terhadap Faktor Selektifitas penisilin G-fenilasetat

\section{Kesimpulan}

Cara ekstraksi membran cair emulsi adalah cara yang efektif untuk memisahkan penisilin $\mathrm{G}$ dari fenilasetat. Hal ini dibuktikan dengan angka selektifitas 21. Pada kondisi ini fasa penerima (internal) lebih banyak mengandung penisilin $\mathrm{G}$ dibanding fenilasetat.

\section{Daftar Pustaka}

Hano, Tadashi, et al.,(1994), "Continuous Extraction of Penicillin G with Liquid Surfactant Membrane Using Vibro Mixer", Journal Membrane Science, 93, 61-68.

Hano, Tadashi., et al.,(1990)," Extraction of Penicillin with Liquid Surfactant Membrane", Journal of Chemical Engineering of Japan, 23, No.6, 772-775.

Mulder, M.,(1996), Basic Principle of Membrane Technology, Kluwe Academic Publisher, London.

Meloan, Clifton E, (1999),Chemical Separations, John Wiley \& Sons,Inc,New York

Reschke,M., Schugerl,K.,(1984)" Stability of Penicillin G in the Presence of Carriers and Relationships for Distribution Coefficients and Degrees of Extraction", The Chemical Engineering Journal, 28, B1-B9.

Reschke, M., shugerl,K., (1984), "Distribution Coeffisients and Degrees of Extraction",The Chemical Engineering Journal „, 28, B11-B20. 